\title{
Management of Soil Contaminants in Guinea - Bissau
}

\author{
Namir Domingos Raimundo Lopes, Yuanyuan Cheng, Wei-lin Shi* \\ Department of Environmental Science and Engineering, Suzhou University of Science and Technology, Suzhou, China \\ Email address: \\ lopesnamir@hotmail.com(N. D. R. Lopes),weilin-shi@163.com(Wei-lin Shi) \\ ${ }^{*}$ Corresponding author
}

To cite this article:

Namir Domingos Raimundo Lopes, Yuanyuan Cheng, Wei-lin Shi. Management of Soil Contaminants in Guinea - Bissau. International Journal of Environmental Monitoring and Analysis. Vol. 6, No. 1, 2018, pp. 26-39. doi: 10.11648/j.ijema.20180601.14

Received: April 16, 2018; Accepted: May 2, 2018; Published: May 22, 2018

\begin{abstract}
Population growth has motivated the gradual increase of agricultural, commercial and mini-industrial activities in Guinea-Bissau. Such activities have been contributing for the generation of certain type's chemical products such as pesticides, fertilizers, plastic bags, hydrocarbons and others, and they are gradually contributing for the increase of harmful chemical wastes and consequently contaminating the environment and the human health since 1960s. Up to now, the country still lacks proper management of soil contaminants, fact that motivate the choice of this research topic in order to help addressing the environmental problems in Guinea-Bissau. This research aims to review the current status of soil contamination in Guinea Bissau, including the technical and regulatory management framework through a series of literature reviews, interviews, site visits and e-mail conversation, to identify the main sources and causes of soil contamination, to determine the effects on the environment and human health, the control and prevention measures including the national and international regulations. Nevertheless, the research found that, all chemicals used in this country are imported and their applications on bare soil are ones of the main causes for soil contamination due to the anthropogenic interest in Guinea-Bissau. Such in the short term can turn into a risk because of its multiplications in soil and inappropriate means of prevention and control of chemical wastes. And it will be visible in a long term due to an eventual transformation of agricultural land into severe infertility, loss of healthy environment and human fragility.
\end{abstract}

Keywords: Population Growth, Pesticides, Fertilizers, Plastic Bags, Environment and Health Impact, Control Measures

\section{Introduction}

Guinea-Bissau is a small country located in the West Africa, bordering Senegal in the north, Guinea Conakry in the East and South; and Atlantic Ocean in the west [1]. The country covers 36,125 square kilometers, ended 2017 with an estimated population of 2 million, which represents an increase of 45,172 people compared to 2016 [1]. The female population is greater, with $52.38 \%$ of the total, compared to $47.62 \%$ men [2]. Guinea-Bissau shows a moderate population density, with 50 people per square $\mathrm{km}$ and it was in position 70th out of 196 countries in the ranking of density population in 2016 [2].

Guinea-Bissau in general is humid tropical with two seasons (Rainy and drought) [3]. The annual temperature under the influence of trade winds varies between 24 and $27^{\circ} \mathrm{C}$ with maximum of $34^{\circ} \mathrm{C}$ [3]. As for the precipitation levels, three large provinces can be distinguished: the South zone, which characterized by the highest annual average of $2000 \mathrm{~mm}$ of rainfall followed by North with annual average variation of $1400 \mathrm{~mm}$ to $1800 \mathrm{~mm}$, and the East with annual average less than $1400 \mathrm{~mm}$ [4].

Gradual population growth has brought some of the disadvantages in term of life's condition in Guinea-Bissau [5]. It has been contributing for high rate of human consumption, increasing the wastes of dangerous chemicals in the environment and affecting the human health. Nowadays, especially in Bissau (Capital city), the import rate of chemicals has increased drastically [5].

The statistics from direction of customs of Bissau, points some chemicals such as pharmaceuticals, Pesticides, Fertilizers, perfumeries, make up and cleaning products, hydrocarbons, paints, liquid and solid soaps including plastics and others, as one of the most imported substances/products in the last few years [6]. These chemicals are imported for the purpose of commercialization 
and services use, for domestic and agricultural activities which end up by contaminating the environment, particularly soil and water resources [6].

\section{Impact of Population Growth on Environment in Guinea-Bissau}

This paper tries to lay emphasis on the Guinea-Bissau environment and its natural resources that are fast being degraded and consumed as a result of human population increase [7]. Thus, this research is aiming to point out the eminent and unavoidable results of continuous increase in human population in Guinea-Bissau. Some of these results are depletion of resources, human congestion, weather modification, high unemployment rate, environmental degradation and more [7]. The overall impact of this growth on the living standards, resources use and the environment will continue to change the Guinea-Bissau's landscape for a very long period of time if nothing is done to checkmate the increasing population including the immigrants from neighboring countries who come and seek for better life in this country [9]. These effects are presently felt most especially in energy consumption, soil contamination/degradation, carbon emissions, air pollution and human congestion [10]. Environmental degradation in Guinea-Bissau results from factors such as population growth, urbanization, commercialization, intensification of Agriculture, rising energy use and transportation [11]. It is therefore safe to conclude that environmental changes in Guinea-Bissau are a result of the dynamic interplay of socio-economic, institution and technological activities. The figure shows the projection of five years difference of population growth in different regions of Guinea-Bissau from 2010 to 2015.

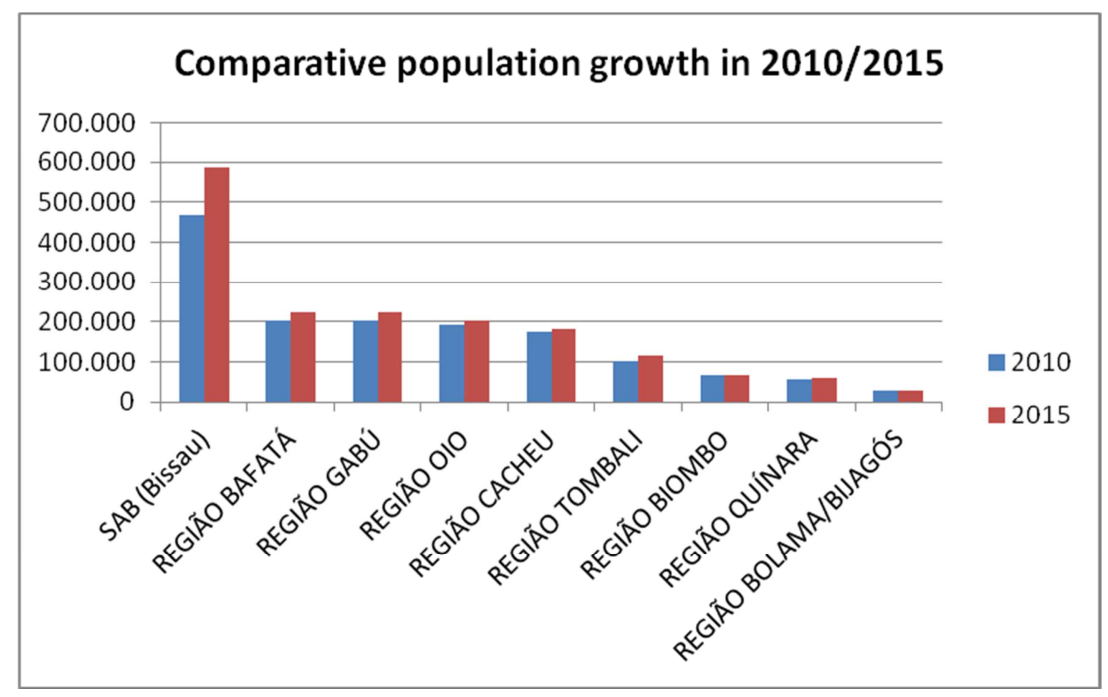

Source: INEC, Projecção Anuais da População por Região 2010/2015

Figure 1. Projection of the population by region of Guinea-Bissau 2010/2015.

\section{Agricultural Soils in Guinea-Bissau}

Agriculture is the dominant sector of the economy in Guinea-Bissau, it represent above $50 \%$ of the GDP and its agricultural soil is divided into three major ecological potentials with a total area of 3,363,700 ha. The current potential farmland in use is $1,410,600$ (ha) which represents about 1.4 ha/farmer [15]. Such types of soil are: Ferra lithic or Fersialitic (soils of the ecology of the plateau) is identified in the most compacted area of the country, larger in terms of the area with total of 1.870. $200 /$ ha, followed by Continental hydromorphic (Bas-funds or small valleys) with total area of 1.032.000/ha and Marine hydromorphic (Mangroves) with total area of 461.500 [15].

Table 1. The three major ecological potentials in Guinea-Bissau.

\begin{tabular}{llll}
\hline Designation of ecology & Total area & Farmland in use & Ecological challenge \\
\hline $\begin{array}{l}\text { Ferra lithic and fersialitic (soils of } \\
\text { the ecology of the plateau) }\end{array}$ & 1.870 .200 & 1.104 .000 & $\begin{array}{l}\text {-Compacted/degraded soil } \\
\text { application }\end{array}$ \\
$\begin{array}{l}\text { Continental hydromorphic soils } \\
\text { (bas-funds soils or small valleys) }\end{array}$ & 1.032 .000 & 200.000 & $\begin{array}{l}\text { - More use of fertilizers/pesticides } \\
\text {-Sedimentation }\end{array}$ \\
$\begin{array}{l}\text { Marine hydromorphic soils } \\
\begin{array}{l}\text { Mangroves) } \\
\text { Total land area }\end{array}\end{array}$ & 461.500 & $\begin{array}{l}\text {-Flooding } \\
\text {-Use of fertilizers/pesticides }\end{array}$ \\
\hline
\end{tabular}


The figures below show the division of the three agricultural potential lands and the total current farmland in use in GuineaBissau.

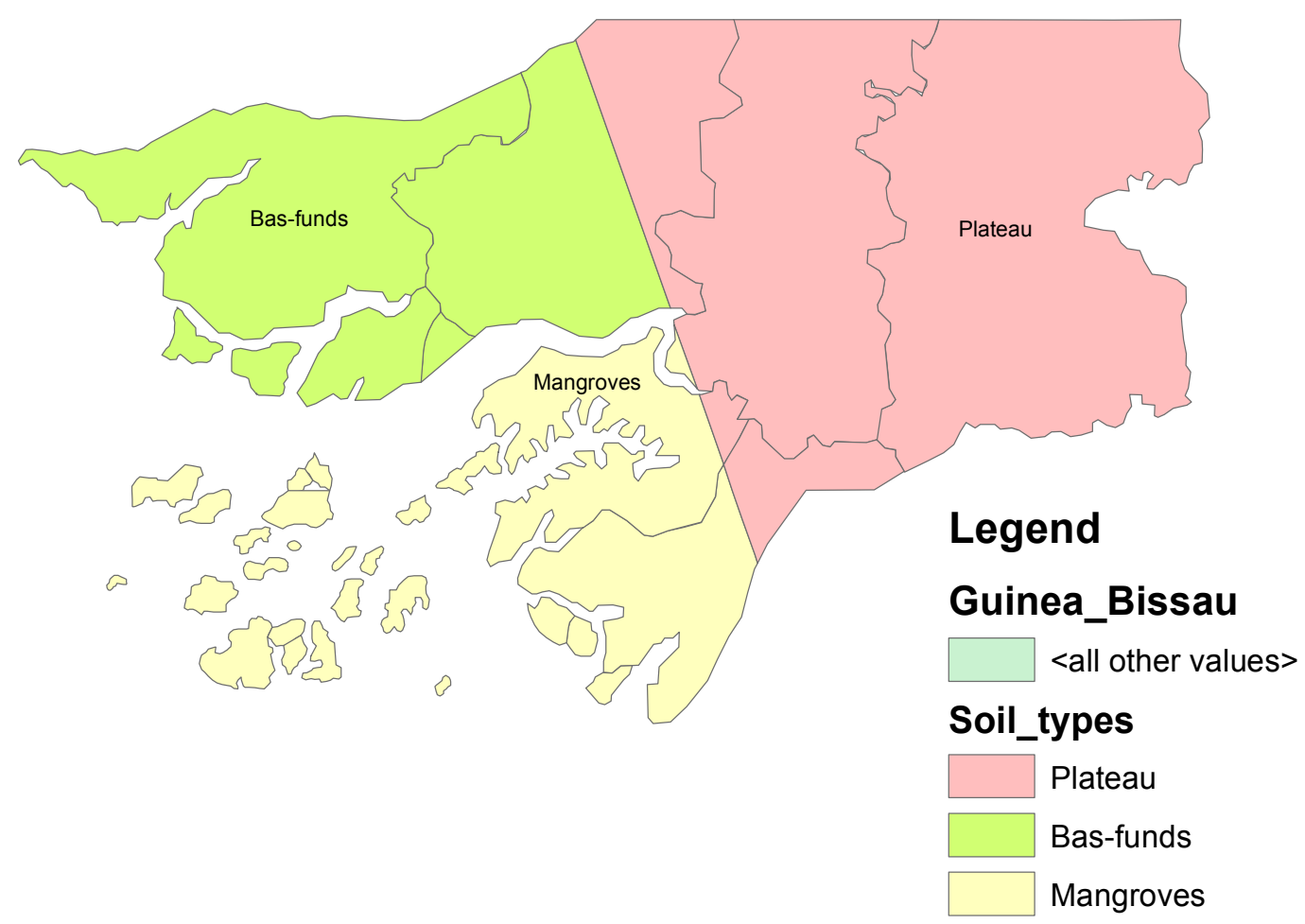

Figure 2. The three types of agriculture land in Guinea-Bissau.

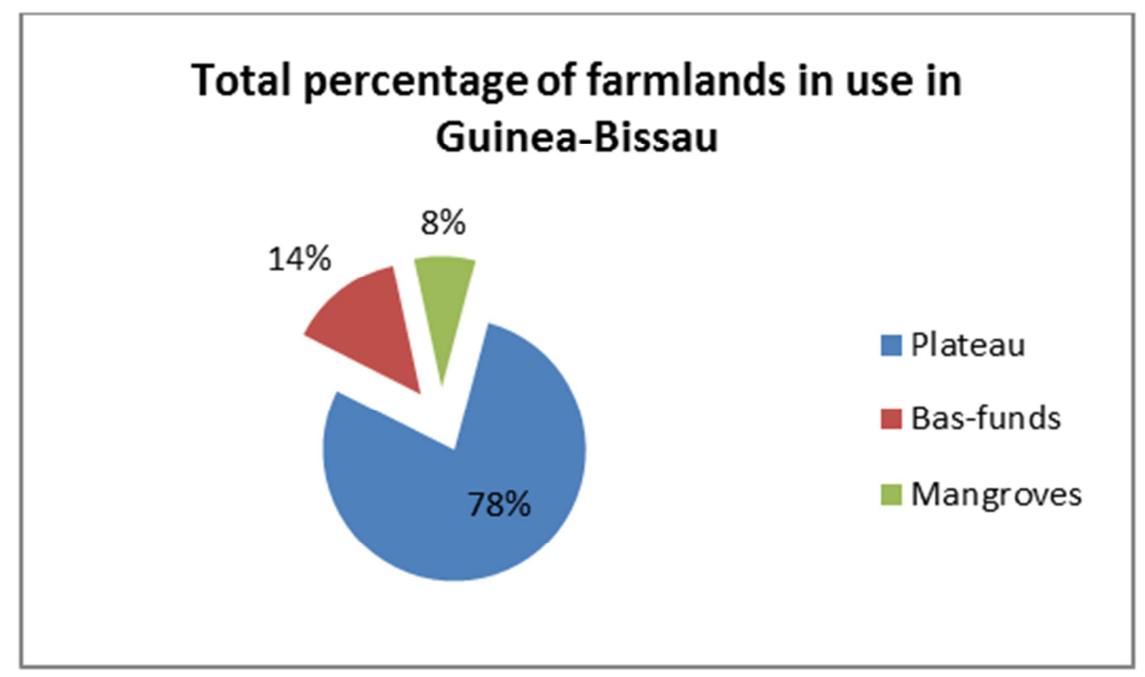

Figure 3. The total farmland in use in Guinea-Bissau.

\section{Imported Chemical Products/Substances in Guinea-Bissau}

Almost everything in life is made of chemicals, the foods people eat contain natural chemicals, like carbohydrates, fats and sugars; the clothes people wear are made from natural substances like cotton, or artificial textiles like polyester; the car people use the drugs people take when are sick or get an injury are all specially developed by chemicals [12]. Guinea
Bissau is not a country of chemical production. All chemicals used in different activities in this country are imported [13]. The figure 2 shows the Customs Statistics of Bissau listed some of the most common chemical substances/products imported in 2015/2016. Such products/substances may contain a lot of contaminants such as heavy metals that are very harmful in environment, particularly in soil and human health [13]. 


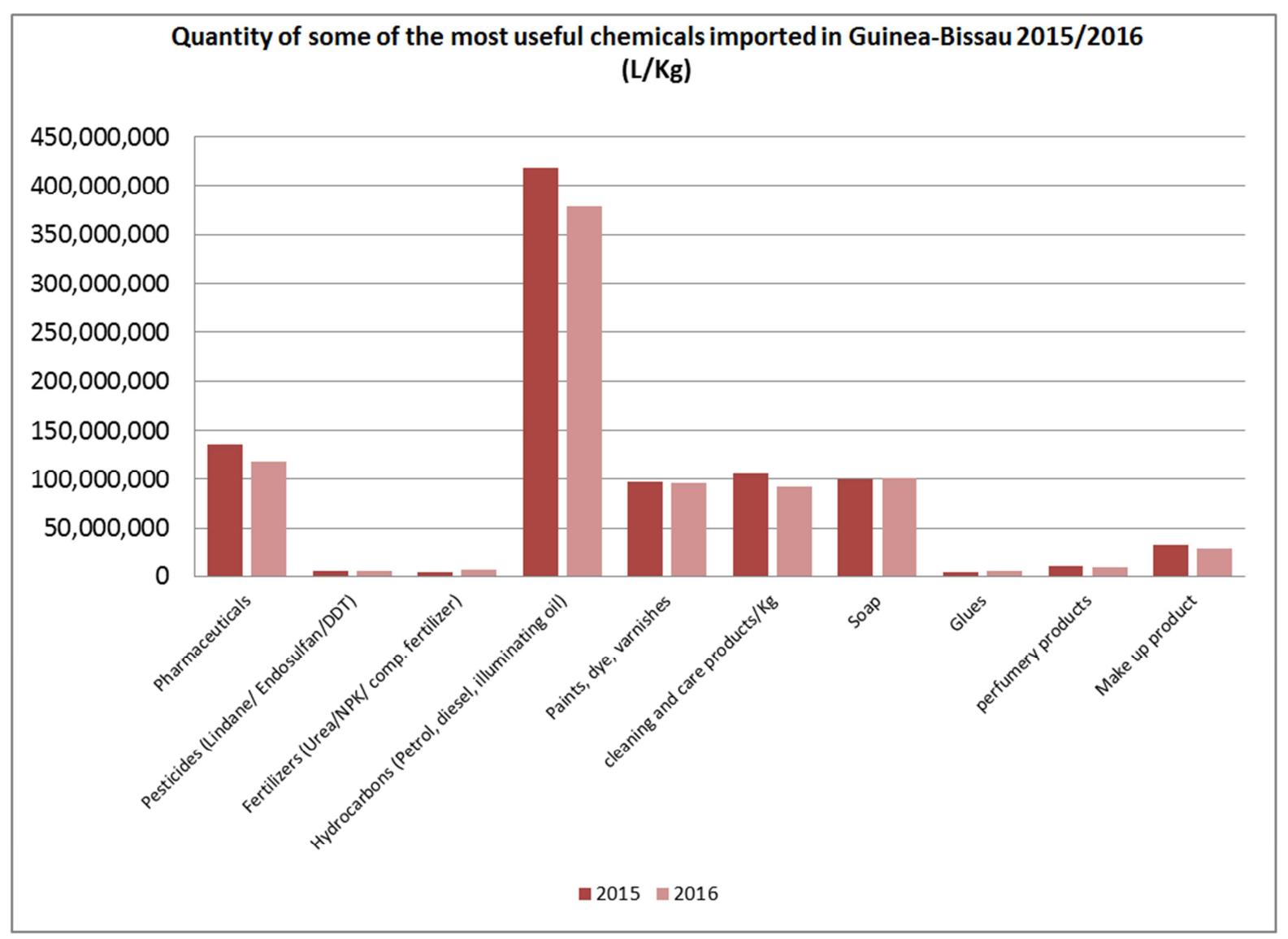

Figure 4. Some of the most useful chemicals imported in Guinea-Bissau in 2015/2016.

Ones of the most harmful chemical in the soil are pesticides and fertilizers. In 2016, such chemicals were imported more in relation to 2015 ; everything indicates that there were more requests from the farmers in this period [6]. In relation to the plastic bags, the data shows the highest import in 2016, the reason was the political instability that the country has known and led some merchants took advantage of the situation to import more plastic bags clandestinely, despite its ban in the market [6]. The hydrocarbons in this case petroleum, diesel, oils and others, are seen as the most imported in the years 2015 and 2016, due to its usefulness in this country. Although in 2016 it represents smaller amount of import, this must be the reason of the political and economic instability that the government has faced in recent years. However these imported chemicals eventually end up depositing in the soil through commercial, agricultural and others activities, affecting the environment and human health [14].

\section{Methodology}

The research strategy is the overall plan for collecting data in order to answer the research questions [16]. The rational for this approach is that the quantitative and qualitative data were both used as part of the strategy; however, quantitative data were more used because it helped to find the information in several levels and in several domains [16].
Quantitative data collection methods include various forms of surveys such as online surveys, paper surveys, mobile surveys and kiosk surveys, face-to-face interviews, telephone interviews, longitudinal studies, website interceptors, online polls, and systematic observations [17]. The tools applied to collect such data include literature reviews, interviews, sites visit, e-mail conversation and other research techniques include both present and historical information.

At the beginning of the process, the respondents were first requested through the formal letters in order to collaborate and facilitate with the necessary information to the extent possible. The questionnaires were elaborated according to the objectives traced and submitted to the respondents through the e-mail conversations and personal meetings. Many questions were answered through the local interviews and others are through e-mail conversations based on the questionnaires.

During the research, the researcher collects two different kinds of data such as primary and secondary data:

a) The primary data were collected through the interviews in different public and private institutions their respective experts and site visits in different locations.

b) Secondary data were collected through the Literature/technical reports in different journals papers, websites books etc. and in different E-mail conversation. The following methodology framework given below summarizes the data collection processes. 


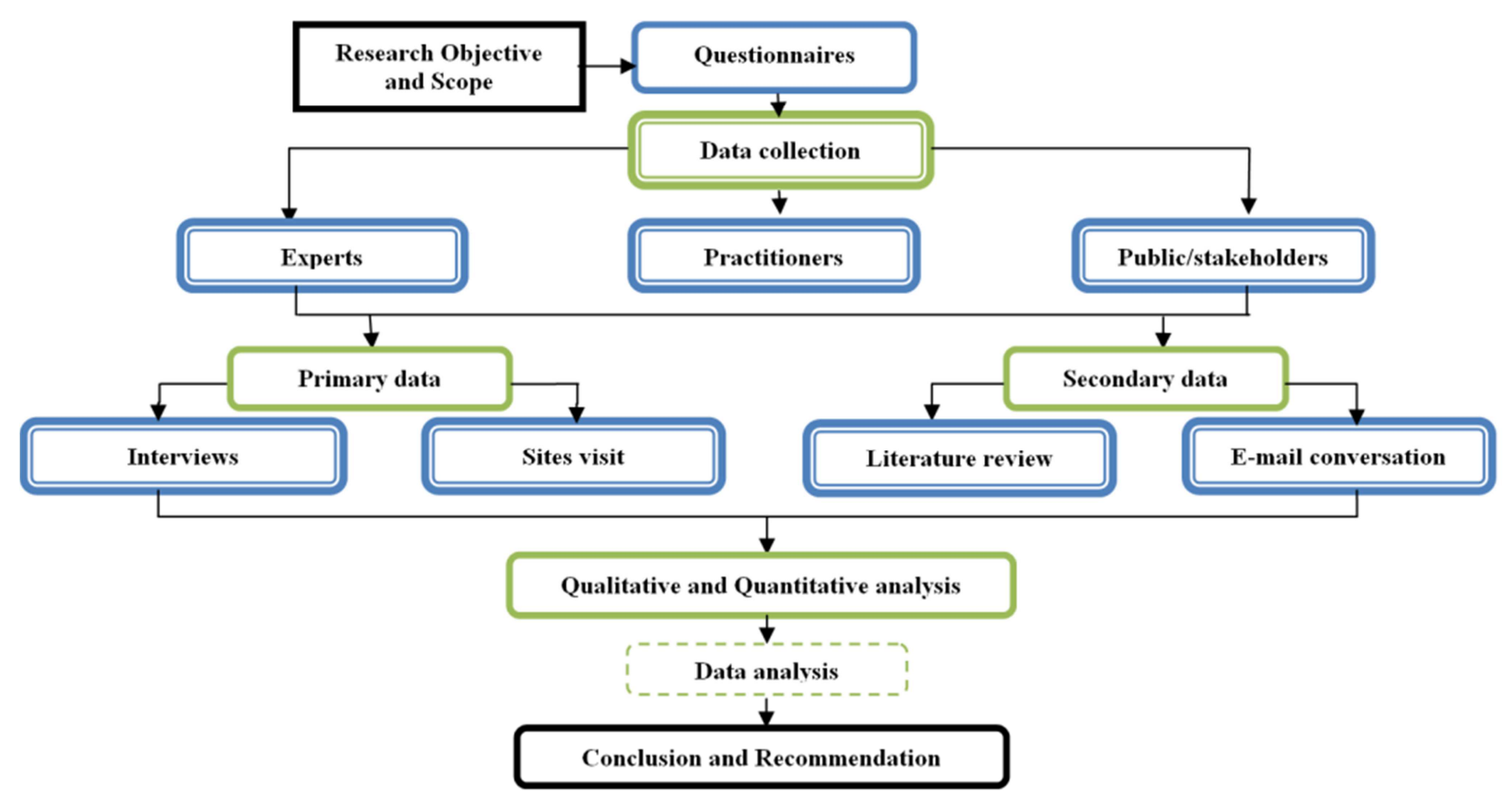

Figure 5. The research strategy framework.

\section{Sources of Soil Contaminants in Guinea-Bissau}

Soil contamination mainly comes from the use of chemical fertilizers, harmful pesticides and insecticides in agriculture and the release of institutional, commercial and industrial waste into the environment which is often full of hazardous substances [18]. The percolation of contaminated surface water to subsurface stratum or improper disposals of wastes are just a few examples causing soil contamination with a variety of inorganic and organic pollutants [18]. Exposure to contamination in soil is often unseen and involuntary but over-time the effects are evident as decreases in soil fertility result in decreases in the soil yield and this also shows up as disruption in the balance of flora and fauna in extreme cases it causes human fatalities [19].

One of the main sources of soil contaminants in GuineaBissau are imported chemicals, including fertilizers and pesticides, the plastic bags that in its composition contain chemicals such as polyethylene, propylene and polypropylene, which will later transform into municipal waste through agricultural activities, commercialization and services [20]. Such activities are responsible for the approximately 2.5 billion tons of wastes produced annually in Guinea-Bissau [20]. Only Bissau represents approximately $65 \%$ of the total wastes produced annually. Waste disposal practices are almost non-existent or inadequate. For this reason, soils maybe contaminated by dangerous chemicals, the infiltrations occur in soil and groundwater and cumulative concentration in man-made species such as fish, vegetables etc [21].

Other sources of soil contaminants in Guinea-Bissau are the large numbers of deteriorating vehicles that consume and release too much engine oil and leaded gasoline, battery leaking etc, to the soil and that contain harmful heavy metal such as lead, cadmium, mercury etc [20]. The habit of some enterprises like car repair shops which in their activities also use engine oil, leaded gasoline, diesel, batteries etc. Locksmiths that deal with several kinds of metal like welding electrodes, irons etc. which in their composition contain cadmium, nickel, chromium, magnesium etc. Carpenters/furniture refinishing which in their activities use woods varnishes, glues etc that contain solvents and thinner, drying oil, resins etc. systematic washing of cars in the public roads that wash out the car wastes such as engine oil, leaded gasoline, diesel, batteries to the soil; production of blocks for houses construction that releasing chemicals such as cement residues etc [20], and more than $95 \%$ of these activities have been doing on bare soil without any protection or treatment systems to prevent or control their chemicals wastes into the environment, particularly the soils [22]. The figures below illustrate only four some of the activities practiced in Bissau, with no minimum working conditions and an inappropriate method of prevention and control of the chemical wastes. 


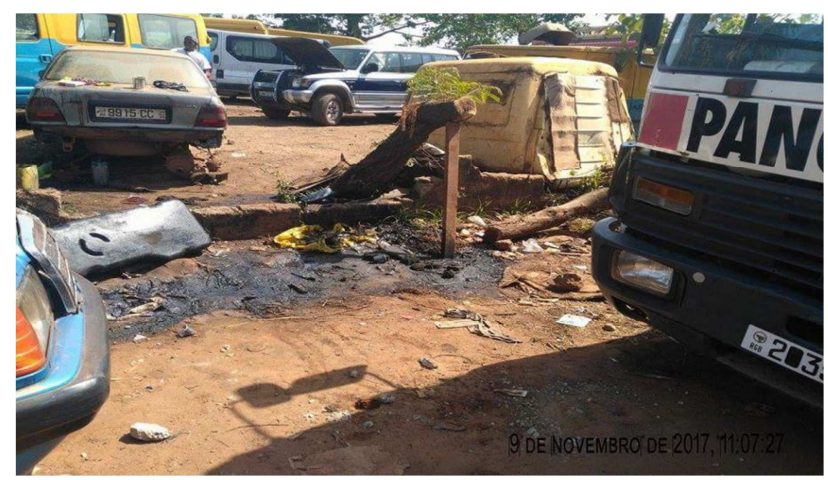

Figure 6. Car workshops activities on the bare soil in Bissau (Mindara district).

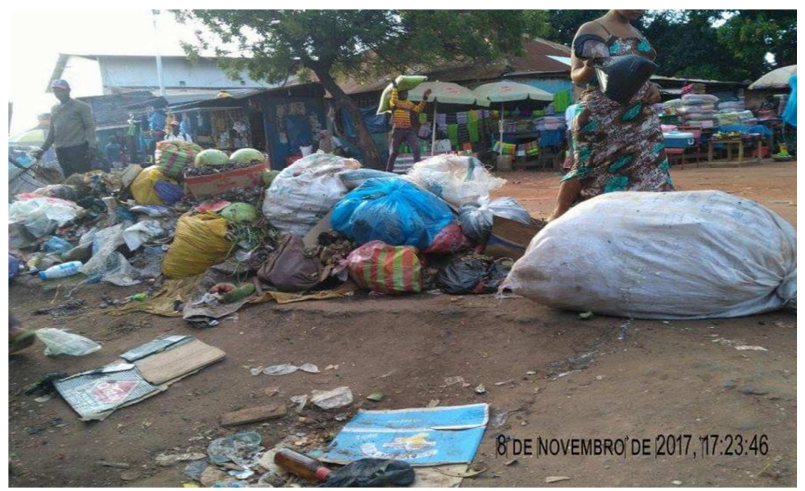

Figure 7. Dump site in Caracol market in Bissau (Bandim district).

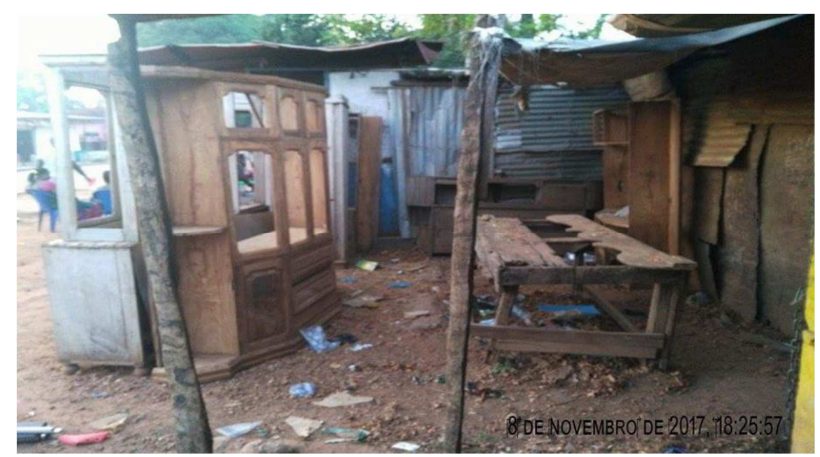

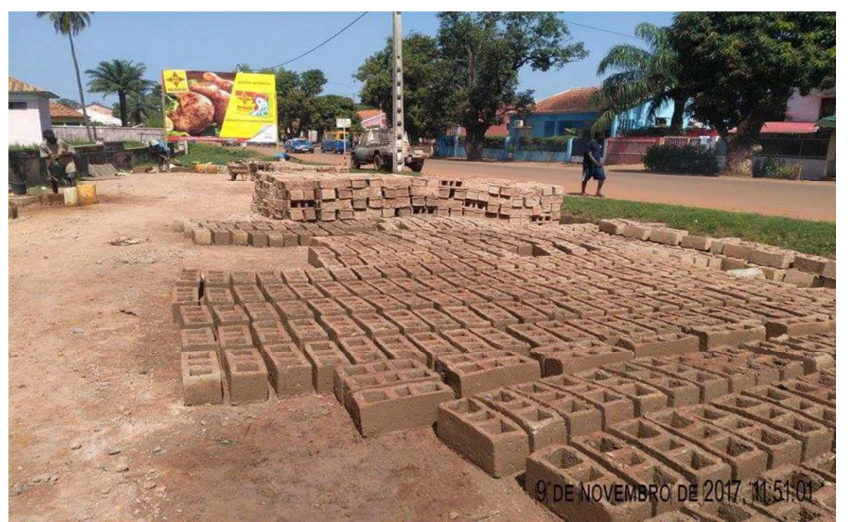

Figure 9. Blocks production activities on the bare soil in Bissau (Cintra district).

\subsection{Use of Pesticides in Guinea-Bissau}

Pesticides are used for a variety of purposes. Pesticide can be defined as a chemical agent designed to destroy unwanted pests [23]. The selection of the best applicable pesticide for the job will directly depend on the actual site's environmental and soil conditions; therefore, without proper knowledge and professional experience in the given job at hand, application of pesticides can lead to unwanted pesticide residue [24].

According to the report from Residues Center of GuineaBissau (2014), the use of pesticides has been increasing gradually due to population growth and need to produce more foods and malaria's control [5]. The government and its partners of development have decided to elaborate the first inventory that was carried out at the country level, specifically in the horticultural women's ranks, at the NGO headquarters (non-governmental organizations) that support farmers at the level of projects in courses and in the old ones, in the State departments that manage phyto-sanitary products, in the informal markets where chemical products are also marketed, etc [25]. Table below shows the summary of imported pesticides in Guinea-Bissau from 2007 to 2011 according to the customs codes associated with the POPs.

Figure 8. Carpentry activities on the bare soil in Bissau (Reno district).

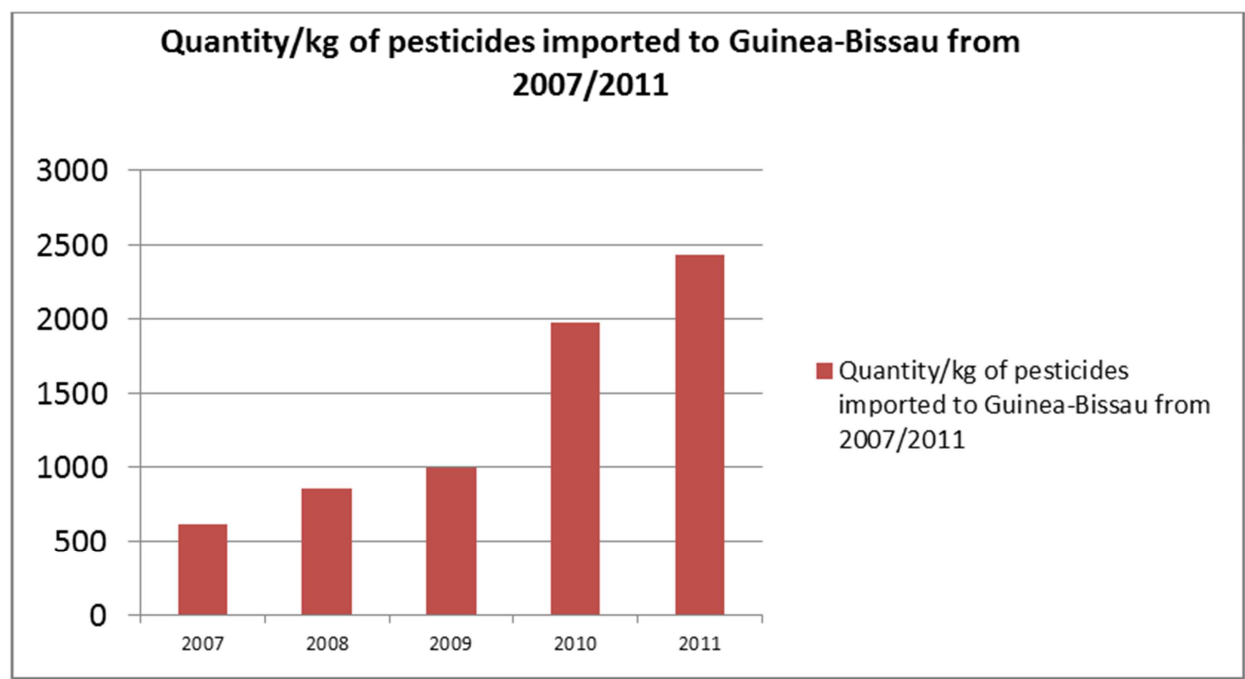

Figure 10. The exporting of pesticides to Guinea-Bissau from 2007/2011. 
Table 2. Exporting of pesticides to Guinea-Bissau from 2007/2011.

\begin{tabular}{lllll}
\hline Year & Export country & Commodity Code & Trade Value (US\$) & Quantity (kg) \\
\hline 2011 & Senegal & 380850 & $\$ 2,472$ & 2.443 \\
2010 & Senegal & 380850 & $\$ 1,992$ & 1.974 \\
2009 & Spain & 380850 & $\$ 1,998$ & 996 \\
2008 & Portugal & 380850 & $\$ 1,936$ & 856 \\
2007 & Portugal & 380850 & $\$ 1,628$ & 614 \\
\hline
\end{tabular}

Source: United Nations database (UN COMTRADE) 2011

The survey found about $14,897 \mathrm{~kg}$ of pesticides imported in 2013 but only $80 \%$ was applied in agriculture land. The government estimated the application of pesticides approximately to about $0.1 \mathrm{~kg} / \mathrm{ha}$ in total of the current estimated agriculture land use 1.410.600. The report aims to carry out an overall assessment and registration of more POPs pesticides in Guinea-Bissau [25]. Guinea-Bissau does not produce POPs pesticides and there is no record of any production activity or formulation of any type of pesticide in its history [26].

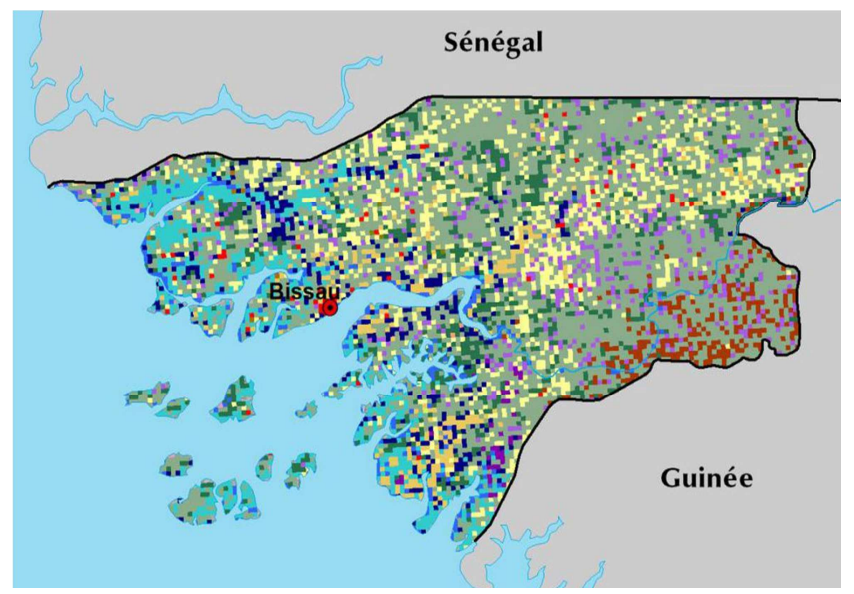

Source: Natural Earth, 2016

Figure 11. The red paint on the map shows the areas of more fertilizer consumption in 2013.

\subsection{Use of Fertilizers in Guinea-Bissau}

Recent studies done by the Ministry of Agriculture and agencies of FAO have emphasized that, synthetic fertilizers are not so heavily used in Guinea-Bissau; however it has been growing tangibly [27]. According to the World Bank data (2017), fertilizer consumption in Guinea Bissau was reported at 6,400 metric tons in 2013 and average of less than $5 \mathrm{~kg} / \mathrm{ha}$. It is noted that, farmers in such country are still using more biological fertilizers than chemical fertilizers [27]. The distributions of chemical fertilizers depend very much on the request of the farmers. Up to now, there is no specific plan of distribution by the Ministry of Agriculture. For instance, the farmers make their own requests according to their needs [28]. The most requested areas identified in the year 2017 are the following sectors: Mansaba, Bigene, Bafata, Gabu, Bissau, and Bambadinca. According Mr. Rui Nené Djata, such kind of fertilizers adapt very well in Ferra lithic and bas-funs soils for the cultivation of rice culture, horticulture, sweet potatoes, fruit culture etc [28]. Data from (2013) with the red paint indicates the use of fertilizers in different parts of the country but with the largest distribution in the eastern region of Guinea-Bissau, which are Bafatá and Gabú due to poor fertility in such areas [27].

\subsection{The Heavy Metal Contaminants in the Soil of Guinea-Bissau}

In recent years, with the development of the urbanization and industrialization both type and content of heavy metals in the soil caused by human activities have gradually increased, resulting in the deterioration of the environment worldwide [29]. Heavy metals are highly hazardous to the environment and organisms and it can be enriched through the food chain. Once the soil suffers from heavy metal contamination, it is difficult to be remediated [30].

Some cities of Guinea-Bissau especially the capital city (Bissau) is apparently very saturated with heavy metal contaminants in the soil taking into account the systematic and persistent use of chemicals on bare soil in different commercial activities such as car workshops, carpentries, blacksmiths, blocks production etc. without a proper management plan that aims to protect or prevent such contaminants into the soil. Such activities generate a lot of chemicals that contain different kinds of heavy metals from batteries, leaded gasoline, engine oil, glues, woods varnishes, cements kilns etc [31]. Base on the activities practiced in this city, it is believable to agree that, the soils of Guinea-Bissau may become contaminated with one of the most harmful heavy metals such as $\mathrm{Cd}, \mathrm{Ar}, \mathrm{Pb}, \mathrm{Hg}$, and Dioxin, and assumed that these dangerous heavy metals have been destroying the environment and human health [31]. Such groups of heavy metal are one of the public health concerns because they are very toxic to human health. Therefore, their proper management should also be the concern of everyone in order to prevent them from contaminating soil and environment [32]. 
Table 3. Sources and effects of chemicals of concerns to public health.

\begin{tabular}{|c|c|c|c|}
\hline $\begin{array}{l}\text { Heavy metal } \\
\text { of concern }\end{array}$ & Soil contaminants form & Human toxicity & Health effects \\
\hline Arsenic & $\begin{array}{l}\text { Pesticides; gold, lead, copper, nickel, iron and } \\
\text { steel mining and/ or processing; coal burning; } \\
\text { wood preservatives. }\end{array}$ & $\begin{array}{l}\text { Main exposure through consumption of } \\
\text { groundwater containing naturally high } \\
\text { levels of inorganic arsenic. }\end{array}$ & $\begin{array}{l}\text { Gastrointestinal tract, skin, heart, liver and } \\
\text { neurological damage, diabetes, } \\
\text { Cardiovascular disease etc. }\end{array}$ \\
\hline Cadmium & $\begin{array}{l}\text { Zinc smelting, mine tailings, burning coal, } \\
\text { batteries, steel, phosphate fertilizers, and metal } \\
\text { plating, sewage sludge etc. }\end{array}$ & $\begin{array}{l}\text { Accumulation in plants and animals, and } \\
\text { farther affect humans who consume } \\
\text { such plats and animal. }\end{array}$ & $\begin{array}{l}\text { Liver and kidney damage, low bone } \\
\text { density and carcinogenic (by inhalation). }\end{array}$ \\
\hline Lead & $\begin{array}{l}\text { Batteries, solder ammunition, paint, ceramic } \\
\text { glaze, fishing equipment, leaded gasoline, } \\
\text { mining, coal burning etc. }\end{array}$ & $\begin{array}{l}\text { Leaded fuel and mining activities are } \\
\text { common causes for elevated lead levels } \\
\text { in topsoil. }\end{array}$ & $\begin{array}{l}\text { Neurological damage, Encephalopathy, } \\
\text { Bone deterioration, Hypertension, Kidney } \\
\text { disease. }\end{array}$ \\
\hline Mercury & $\begin{array}{l}\text { Electrical switches, fluorescent light bulbs, } \\
\text { lamps, batteries, scale gold mining, pesticides, } \\
\text { medical waste, fuel oil etc. }\end{array}$ & $\begin{array}{l}\text { Contaminated seafood. For } \\
\text { Children are direct ingestion of soil. }\end{array}$ & $\begin{array}{l}\text { Central nervous system (CNS) and gastric } \\
\text { system damage, affects brain development, } \\
\text { liver, heart and kidney damage etc. }\end{array}$ \\
\hline Dioxin & $\begin{array}{l}\text { Waste incineration, reprocessing metal } \\
\text { industry, contaminated herbicides etc. }\end{array}$ & $\begin{array}{l}\text { Human exposure is through food, } \\
\text { mainly meat and dairy products, fish and } \\
\text { shellfish. }\end{array}$ & $\begin{array}{l}\text { Reproductive problems damage the } \\
\text { immune system, interfere with hormones, } \\
\text { cancer. }\end{array}$ \\
\hline
\end{tabular}

\subsection{Use of Plastic Bags in Guinea-Bissau}

Pollution from plastic bags is a major threat in the environment, in which Guinea-Bissau has now declared war, with a new law almost unheard in Africa [33]. The concern with this problem is so much that led the government approved the decree law $\mathrm{n}^{\circ} 16 / 2013$ on the prohibition of manufacture, importation, the marketing and distribution of plastic bags. The latest statistics from the general direction of the customs of Bissau indicate that in 2016 more 7,000 kilograms of plastic bags were imported, an average less than $15 \mathrm{~kg} / \mathrm{capita}$ annually [34]. Guinea-Bissau does not produce any type of plastic bags, all plastic bags used in this country are imported which contribute in generation of more than 250 tons of solid wastes daily in Bissau [35] The government, as an alternative, the National Press made biodegradable paper bags available at a cost similar to the bags previously in circulation, but such measure has generated some unease among traders [36]. In addition, these called for a transitional period for law enforcement, during which the government admits the sale in parallel. Even with this law, traders continue to take advantage of the vulnerability and fragility of the country by importing plastic bags in a clandestine way [37]. The figure below shows the gradual increase of plastic bags from 2012 to 2016 in Guinea-Bissau due to poor control of use, marketing; high dependence of precarious citizens on that business and poor law enforcement to ban the practice. Such product is made of phthalate, a very harmful chemical which is affecting the environment and humans health.

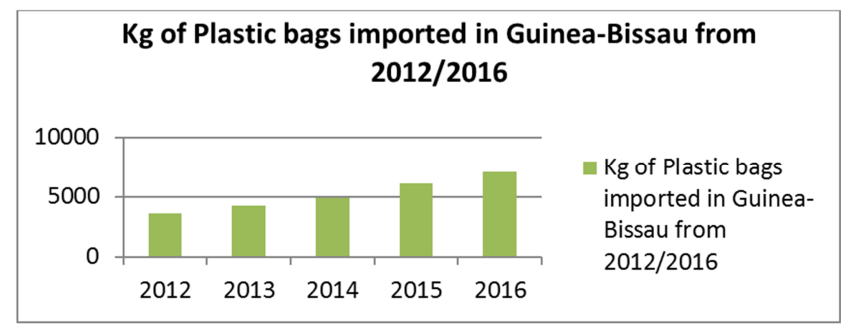

Figure 12. Kilograms of plastic bags imported in Guinea-Bissau from 2012/2016.

\section{Effect of Contaminated Soil on the Environment and Human Health in Guinea-Bissau}

Contaminated soil directly affects human health through direct contact with soil, via ingestion or inhalation which has vaporized; potentially greater threats are posed by the infiltration of soil contaminants into groundwater aquifers for human consumption [38]. The health consequences from exposure to soil contamination depend on the type of contaminants, pathway of attack and vulnerability of the exposed population [39].

Industrial or man-made concentrations of naturally occurring substances, such as nitrate and ammonia associated with livestock manure from agricultural operations, have also been identified as health hazards in soil and groundwater [40]. Chronic exposure to cadmium, lead and other heavy metals from petroleum, solvents, and many pesticides and herbicides formulations can be carcinogenic, can cause congenital disorders, or can cause other chronic health conditions [41]. For instance, it has confirmed by the Ministry of Agriculture report of Guinea-Bissau that the officials responsible for the management of pesticide depots of the called service director, curiously in different localities all died without reaching the retirement age [42]. This leads us to very likely admit that they are related to the health impacts of pesticides. Also assume that, people who live around these warehouses may become contaminated by these harmful chemicals due to overdose and inhalation [42].

It is to be regretted that the country does not have the information or national mechanisms to make appropriate assessments of these situations and there is no specific data from public health showing the number of children affected by soil contaminants in Guinea-Bissau. However it is assumed, many children could become contaminated or affected by such contaminants due to their vulnerability, lack of proper hygiene and their systematic contact with soil during their playing on the ground in the contaminated areas [42]. The report also details in some areas of Guinea-Bissau, the nutrients that have been added in the soil whether manure 
or domestic wastewater; or chemical fertilizers have been contributing for the concentration of contaminants in the soil by agricultural interests to increase more crop yields [43]. The evidence is the eutrofication found in some stagnated water, especially those that are near the farm lands, as well as plastic bags of some time to here especially in Bissau the capital and the most populous city, have built up a great danger to the environment, mainly in the soil and water.
Flood completely the streets and markets, where they form authentic mountains of wastes, plugging the drainage channels for drainage of rainwater, fact that allows the rainwater to washout certain amount of contaminants to surrounding people [35]. Children are also seen as the major target of such contaminants in soil and water due to their vulnerability.

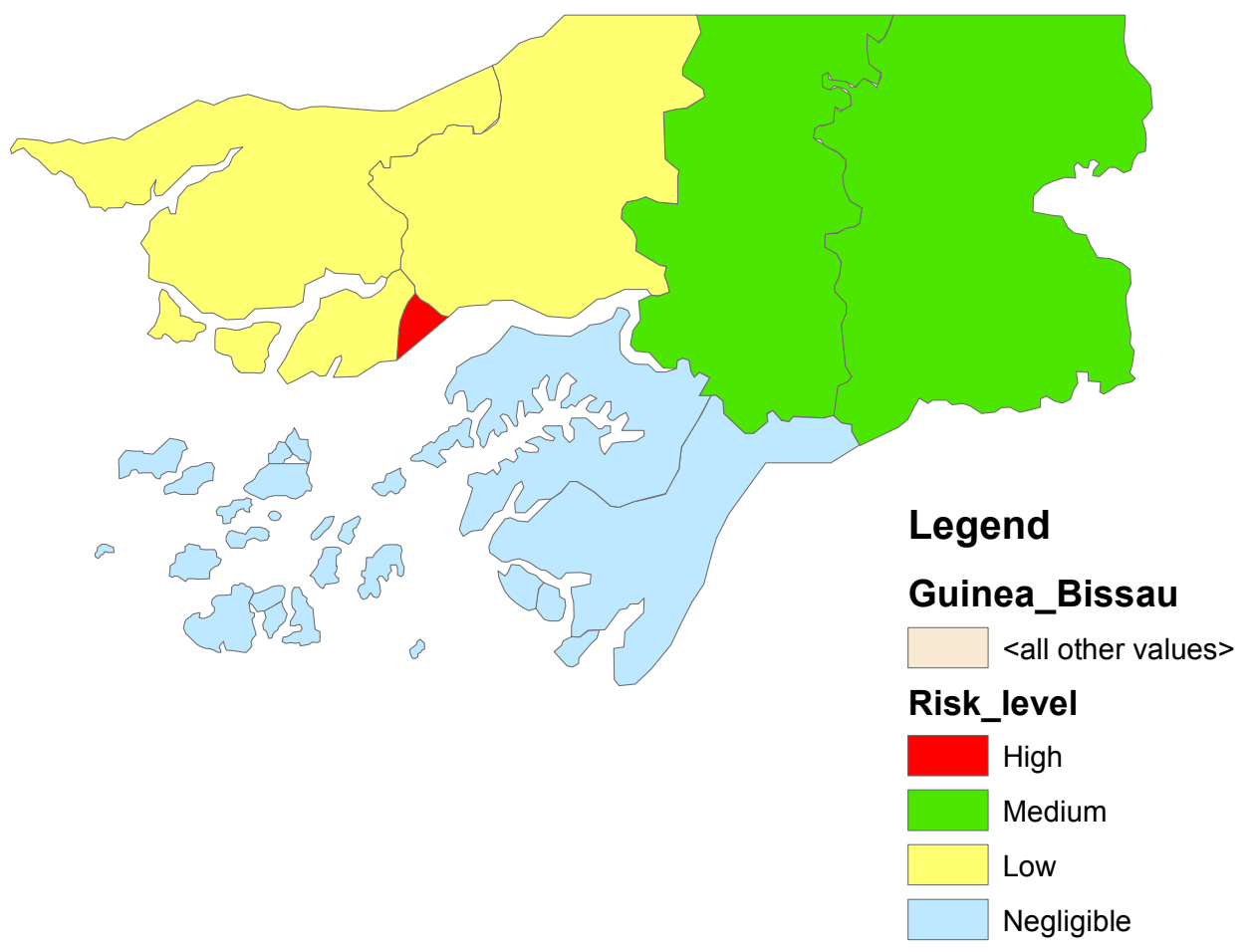

Figure 13. Regions with more risks of soil contamination in Guinea-Bissau.

The figure explains the regions with more risks of soil contamination accordingly, where Bissau is ranking with the High risk in the environment and human health due to huge population growth, high level of commercial and mini industrial activities on bare soil and with insufficient facilities for proper management of chemical wastes. Bafáta and Gabú are representing Medium risk due to the gradual increase of population, the area with more applications of fertilizers and pesticides for agricultural purpose and gradual increasing of commercial mini-industrial activities and with poor management of chemicals wastes. Oio, Cacheu and Biombo are considered Low risk due to small population, lower application of chemicals in agriculture activities, and few commercial and mini-industrial facilities etc. While Tombali, Quinara and Bolama are seen as Negligible risk due to their least population, the regions with almost no application of chemicals in agriculture activities due to good fertility of the soils and few commercial and mini industrial operation around these areas.

The criteria used to determine the risk level are based on population growth, the area with most commercial, miniindustrial and agricultural activities and waste control facilities available in these areas.

\section{Prevention and Control Measures for Soil Contaminants in Guinea-Bissau Including Some International Conventions}

Soil contaminants can be controlled or at least reduced by sensitizing ourselves on the cause and effects of soil contaminants and elect some ways that can help reducing or stop it [40]. In addition, one of the ways is to contribute less waste to help prevent soil contamination, purchase glass and other reusable containers instead of throwing away plastic or paper regularly, recycle paper and plastic through your local waste management company to reduce the amount of waste that is sent to a landfill [44]. Lobby your community to adopt ways to treat waste before disposing it to prevent pollution and contamination. Waste that is biodegradable should be broken down in a controlled environment before being disposed off [45].

In attempt to reduce or prevent the wastes, especially soil contaminants, the government of Guinea-Bissau has decided to: 
a) Create and funding a project called "Bissau Cidade Limpa" to help in removal and treatment of wastes [46].

b) Ministry of Agriculture, with the support of its partners of development such as FAO, WFP, World Bank, European Union etc. have provided several awarenessraising, training and training programs for farmers in the management of fertilizers and pesticides since these chemicals are very harmful for plants, animals and humans who deal or consume those plants or animals [43].

c) Some awareness programs that have been carrying out in medias, promoted and supported by the government and some NGOs (Non Government Organizations) including IBAP (Instituto da Biodiversidade das Areas Protegidas) in order to help educating people about the prevention and conservation of the natural resources and the environment [47]. Such programs have helped a lot in awareness of both urban and rural areas. Although there are still a lot gaps that need to be sorted out by adopting specific regulations and government policies that aims to protect, prevent and control the contaminants in soils [47].

d) The government legislation on decree law $n^{\circ} 16 / 2013$ that prohibited the manufacture, import, the marketing and distribution of plastic bags [33]. And the Decree Law $n$ 7/2000, on pesticides use. This national legislation allows, establish a type-approval system in all countries of the Inter-State Committee to Combat Drought in the Sahel (CILSS). Restrict in principle the use of less toxic products through FAO / WHO classification. Establish guidelines based on FAO directives on warehouse security, transport, sales, application, etc [48].

e) Correct and rectifies of the Stockholm Convention on POPs use as well as Rotterdam Convention with purpose of protecting the environment and human health. Such convention was ratified by the National People's Assembly through resolution 20/2005, later promulgated under the Presidential Decree No. 19/2009 [49]. It is good to say that there is no law that prohibits or restricts the use of any type of pesticide in GuineaBissau. However, this country is observing such law through the Stockholm and Rotterdam Convention [48]. This strategy of government aims to reduce the contaminants in the soils and all environments.

According to the CAIA (Environmental Impact Assessment Cell) of Guinea Bissau (2017), the government has adopted series of measures that have been implemented in few years ago. Some the measures listed in the table bellow, aimed to prevent and control certain kinds of soil contaminants particularly those considered very harmful in the environment and human health [50].

Table 4. Some of the measures adopted by the government of Guinea-Bissau from 2000/2014.

\begin{tabular}{lll}
\hline Year & Government Policy & Institution \\
\hline 2014 & Increase group of waste divers and waste removal in districts. & Department of Sanitation \\
2011 & Restrict the car washing activities in public. & Town hall of Bissau \\
2010 & Register and inspect work condition of certain mini-industries. & General Direction of Industry \\
2002 & Apply more fees to the second hand vehicles. & Ministry of Finance and Economy \\
2000 & Control of chemicals inlet in the customs and their destinations. & Costumes Department \\
\hline
\end{tabular}

Source: INE, July 2015

\subsection{Stockholm Convention}

The Stockholm Convention on Persistent Organic Pollutants (POPs) was adopted by the Conference of Plenipotentiaries on $22^{\text {nd }}$ May 2001 in Stockholm, Sweden. The Convention entered into force on $17^{\text {th }}$ May 2004. Guinea-Bissau correct and rectifies the Stockholm Convention On August $6^{\text {th }} 2008$ on POPs use. At present, the Stockholm Convention is signed and ratified by 181 countries with the objectives of protecting the human health and the environment from Persistent Organic Pollutants (POPs) [51]. The Convention provides a framework, based on the precautionary principle, for the elimination of the production, use, import and exports of twelve priority POPs, their safe handling and permanent disposal and the elimination or reduction of unintentional releases of certain POPs. The control measures defined in the Convention are being implemented by regional community legislation where Guinea-Bissau is an integral part, namely the CILSS (InterState Committee for Combating Drought in the Sahel) [52]. Guinea-Bissau has drawn up its first Action Plan for the implementation of the Stockholm Convention in 2012 [53].
This report aims to carry out an overall assessment and registration of more POPs pesticides, whether produced or imported, included in the Annexes of the Convention, in particular: A: Aldrin, Endrin, Mirex, Chordane, Heptachlor, Toxaphene, Deldrin, Hexachlorobenzene; B: DDT and new pesticides POPs: Alpha hexachlorocyclohexane, Beta hexachlorocyclohexane, Chlordecone, Pentachlorobenzene, Technical endosulfan their isomers is also included "Lindane" (gammahexachlorocyclohexane) [53].

The Stockholm Convention on Persistent Organic Pollutants advocates, elimination of the above-mentioned POPs, intentionally produced or imported listed in Annex A, DDT included in Annex B, for its reduction, although it is still illegal but continue to be used for vector control (fundamentally, the mosquito that transmits malaria). The Parties are further obliged to "take regulatory action to prevent" the production and use of any new POPs [53].

\subsection{Rotterdam Convention}

Rotterdam Convention is an international treaty promoting shared responsibility between exporting and importing 
countries in protecting human health and the environment from certain banned and restricted hazardous chemicals and pesticides; and providing a mechanism for the exchange of information about potentially hazardous chemicals [54]. The Convention was adopted on 10 September 1998 in Rotterdam, the Netherlands and entered into force on 24 February 2004. More than 150 countries have ratified the convention. The chemicals listed in Annex III include pesticides and industrial chemicals that have been banned or severely restricted for health or environmental reasons by two or more Parties [54]. There are a total of 51 chemicals listed in Annex III, 36 are pesticides (including 5 severely hazardous pesticide formulations) and 15 industrial chemicals. Guinea-Bissau signed the Rotterdam Convention on 10 September 1999 and on $2^{\text {nd }}$ March, 2005 it was ratified [55]. The key actions focus on drafting national legislation on chemicals set out in Annex III of the Rotterdam Convention and implementation strategy at national level for avoiding risks from the use of pesticides and an impact on human health [54]. The process of signing and ratifying the Rotterdam Convention on Prior Informed Consent Procedure for Certain Agrochemicals and Hazardous Chemicals Subject to International Trade was piloted by the Ministry of the Environment, similar to the Basel and Stockholm Conventions [56]. Therefore the technical and practical implementation of the Rotterdam Convention is being implemented by the Ministry of Agriculture through its Vegetation Protection Service which is the National Focal Point and also plays the role of DNA [56].

\section{Result and Discussion}

Few researches and studies have been done mainly on the real problems of soil contamination in Guinea-Bissau, the evidence of this has to do with the insufficient information found or made available in journals, websites etc. However, through the surveys and data available, it is found that, the increasing population has motivated the increasing rate of chemical imports and consumption in Guinea-Bissau. Mainly pesticides, fertilizers, plastic bags and others; and such have been identified as ones of the main contributors of soil contamination in such country. The survey also found that there are some people including children, suspected of being affected by soil contaminants, but no official data were found in public health to prove the fact. And some measures taken by the government and other organizations to protect the environment were not sufficient and they lack a clear and objective policy to stop bottlenecks. It is noted that there is no specific law aimed at protecting and controlling GuineaBissau's soils from hazardous contaminants.

In the course of the interviews conducted by the researcher during the summer vacations in July and August of 2017 in Bissau, several illustrious experts were also unanimous in pointing out that, the gradual population growth in such country has contributed to the increase of commercial, mini industrial and agriculture activities, which consequently increase the hazardous contaminants in the environment, mainly in the soil and affecting the life of people. Such exercises greatly contribute to the researcher being able to identify:

a) The main sources of soil contamination Guinea-Bissau;

b) Identifying the presumed contaminated areas and people;

c) Some measures adopted by the government to reduce the pollutions and contaminants in the environment;

Despite some field works were done in different districts of Bissau with the aim of bringing the images that illustrate some of the activities that are contributing in the generation of soil contaminants in Guinea-Bissau.

It was concluded that Guinea-Bissau still not have large industrial activities that contribute to heavy contamination and degradation of the environment, but commercial and agricultural activities are gradually growing up with tangible application of harmful chemicals. Such in the short term can turn into risk with the accumulation of the soil contaminants due to its multiplications accompanied by lack of appropriate means of prevention and control of chemical wastes. The effect of these contaminations will be visible in a long term due to an eventual transformation of agricultural land into severe infertility, loss of healthy environment and human fragility.

\section{Conclusion and Recommendations}

It is regrettable that, all these problems are happening in a country where there are almost no waste treatment plant and proper structure that can help in the prevention and control of the chemical wastes that are multiplying and spreading in the soil day by day with the poor engagement of the competent authorities and specific legislations that can help regulate such hazardous chemicals in soil.

In an attempt to find good solutions for the environmental problems in Guinea-Bissau, regarding to management of soil contaminants, several literatures works were appreciated, especially those almost similar with problems of GuineaBissau. In the processes of revision, the literature of the developing countries have been privileged, especially those who have presented problems of soil contamination whether in the past or in the present.

Although the current level of contamination in GuineaBissau does not pose great risks to the environment and human health, but it is necessary to find urgent solutions in order to help controlling the use of plastic bags, pesticides, fertilizers and others chemicals. Such solutions necessarily involve:

a) The establishment of several offices with the mandate of identifying, controlling and register all chemical products used in Guinea-Bissau. These offices should be decentralized in all regions of Guinea-Bissau, composed of competent persons capable to identify and prevent the environmental problems;

b) The government must force all operators of the industries above all those who apply chemicals in their activities to improve their working conditions (control of chemical residues in soil); 
c) Involvement the Ministry of Social Communication in the sense of promoting educational programs on environmental protection through social media. This will likewise help in the moralization of people;

d) Government through the Ministry of Public Health must be able to persuade its partners of development through a credible project to allocate funds that will help providing the appropriate assessments of the situations below:

1. Specialized centers for clinical analyzes related to the risks of pesticides in the blood;

2. Technologies and material resources for the decontamination of contaminated sites;

3. Training of sufficient human resources capable of carrying out studies related to environmental and health impacts by pesticides POPs;

4. Available toxicological records and specialized hospitals to deal with these situations;

\section{Future Research}

It is well noted that this research lacks some of important data during the surveys, and there are several gaps regarding to scientific studies that did not allow identifying some of the important data such as:

1. An obvious study that identifies the concentration of heavy metal in soil of Guinea- Bissau;

2. Credible data that explains numbers of individuals affected by soil contaminants in Guinea-Bissau;

3. Studies on the identification of areas with more consumption of pesticides and chemical fertilizers;

4. A study on the identification of the key prevention and control measures for chemical wastes in GuineaBissau;

Such gaps will motivate the continuity of this research in a very near future, due to its pertinence. The researcher also elected two more environmental problems that have been affecting the life of people in Guinea-Bissau, to be investigated or researched in the near future such as:

1. Management of municipal solid waste and;

2. Factors of the degradation of agricultural land in Guinea-Bissau;

These problems deserve a great attention from the researcher and entities in order to help find viable solutions for the country and for the well-being of the whole population.

\section{Acknowledgements}

Foremost, I would like to express my sincere gratitude to Suzhou University of Science and Technology (School of Environment Science and Engineering). Very special thanks for my Supervisors and Co-supervisor respectively Professor Weilin Shi and Dr. Yuanyuan Cheng for the great contribution in my research, also thank all those who have contributed in providing several important data and for their encouragement to this paper become a reality.

\section{References}

[1] BBC. Guinea-Bissau country profile. BBC News. [Online] August 1, 2017. [Cited: December 27, 2017.] http://www.bbc.com.

[2] Worldometers. Guinea-Bissau Population. Worldometers. [Online] December 26, 2017. [Cited: December 27, 2017.] $\mathrm{http} / / / \mathrm{www}$.worldometers.info.

[3] UNDP. THE REPUBLIC OF GUINEA-BISSAU: STRENGTHENING RESILIENCE AND ADAPTIVE CAPACITY TO CLIMATE CHANGE IN THE AGRARIAN AND WATER SECTORS. Bissau: Enveronment and Energy, 2015.

[4] Distribuição espacial de valores prováveis de precipitação pluvial para períodos quinzenais, em Guiné-Bissau. Sadjo Danfá, Antônio M. da Silva, Carlos R. de Mello, Gilberto Coelho, Marcelo R. Viola and Léo F. Ávila. 2014, agriambi, pp. 67-74.

[5] Cunha, Dr. Laurentino Rofino da. effect of increasing population in Guinea-Bissau. [interv.] Namir Domingos Raimundo Lopes. July 23, 2017.

[6] DGA. [interv.] Namir Domingos Raimundo Lopes. August 13, 2017.

[7] INE. populaçao da Guiné-Bissau. http://www.statguinebissau.com/. [Online] December 2nd, 2017. [Cited: December 2nd, 2017.]

[8] Population diversity: Its extent and extinction. Hughes, J.B., G.C. Daily and P.R. Ehrlich,. 2015, Science, 278:, pp. 689692.

[9] UNDP. Human Development Report in Guinea-Bissau. Guinea-Bissau: UNDP, 2016.

[10] World Bank. Economia da Guiné-Bissau. Bissau: Planeta Vida, 2014.

[11] DENARP II. Segundo Documento de Estratégia Nacional de Redução da Pobreza. Bissau: MINISTÉRIO DA ECONOMIA, PLANO E INTEGRAÇÃO REGIONAL, 2011.

[12] Role of Chemistry in Everyday Life. Sunita B. 2016, Chemistry and Chemical Sciences, pp. 192-198.

[13] UNITAR. PERFIL NACIONAL PARA AVALIAR AS CAPACIDADES DO PAÍS NA GESTÃO DOS PRODUTOS QUÍMICOS. Bissau: UNITAR, 2016.

[14] DGA. [interv.] Namir Domingos Raimundo lopes. January 20, 2017.

[15] Djatá, Rui Nené. [interv.] Namir Domingos Raimundo Lopes. July 27, 2017.

[16] Sudeshna, Shruti Datt and. Defining research strategy in a research paper.

https://www.projectguru.in/publications/research-strategybusiness-studies/. [Online] September 14, 2016. [Cited: December 2nd, 2017.]

[17] DeFranzo, Susan E. difference between qualitative and quantitative research. https://www.snapsurveys.com/blog/qualitative-vsquantitative-research/. [Online] September 16, 2011. [Cited: December 2nd, 2017.] 
[18] Sources of Soil Pollution. Mirsal, Ibrahim A. 2015, Springer Link, pp. 137-173.

[19] WHO. Contaminated sites and health. Italy: World Health Organization, 2014.

[20] Dias, Odoneo. The main soil contaminants in Guinea-Bissau. [interv.] Namir Domingos Raimundo Lopes. August 4, 2017.

[21] Djatá, Rui N. [interv.] Namir Domingos Raimundo Lopes. July 15, 2017.

[22] Vaz, Eng. Faustino Soares. commercial and industrial activities in Guinea-Bissau. [interv.] Namir Domingos Raimundo Lopes. August 13, 2017.

[23] WHO. Pesticides. s.1.: who, 2015.

[24] Effects of Pesticides on Environment. Hakeem, Khalid Rehman. 2016, Springer International, pp. 3-13.

[25] UNEP. Rotterdam Convention on the social and environmental impact of pesticide use. s.1.: Rotterdan Convention, 2015.

[26] Stockolm Convention. POPs Enabling Activities Republic of Guinea-Bissau. Bissau: Stockolm Convention, 2013.

[27] World Bank. fertilizer consumption in Guinea Bissau. Bissau: World Bank, 2017.

[28] Djatá, Rui Nené. [interv.] Namir Domingos Raimundo Lopes. July 18, 2017.

[29] Effect of fertilizer application on soil heavy metal concentration. Ahmadimoghaddam, Zahra AtafarAlireza MesdaghiniaJafar NouriMehdi HomaeeMasoud YunesianMehdi. 2010, Environmental Monitoring and Assessment.

[30] Hazards of heavy metal contamination. Järup, Lars. 2015, academic.oup.com, pp. 167-182.

[31] Cunha, Laurentino Rofino. the most typical soil contaminants in Guinea-Bissau. [interv.] Namir Domingos Raimundo Lopes. July 20, 2017.

[32] Toxicity, mechanism and health effects of some heavy metal. Monisha Jaishankar, Tenzin Tseten, Naresh Anbalagan, Blessy B. Mathew and Krishnamurthy N. Beeregowda. 2014, NCBI, pp. 60-72.

[33] DW. Guiné-Bissau proíbe o plástico. DW. [Online] September 4, 2014. [Cited: Demceber 23, 2017.] http://www.dw.com.

[34] INE. Estatisticas do Comércio Externo. Cabo-Verde: INE, 2016.

[35] ANGOP. Guiné-Bissau: Capital guineense produz diariamente 250 toneladas de lixo. ANGOP. [Online] Junho 4, 2015. [Cited: December 23, 2017.] http://www.angop.ao.

[36] DW. Guiné-Bissau proíbe o plástico. DW. [Online] September 4, 2013. [Cited: Demceber 23, 2017.] http://www.dw.com.

[37] Lopes, Joao R. Poluiçao de socos plasticos na Guiné-Bissau. [interv.] Namir D. R. Lopes. August 6, 2017.

[38] KENNEDY, A. L. The Effects of Soil Pollution on Humans. livestrong. [Online] June 13, 2017. [Cited: December 24, 2017.] https://www.livestrong.com.

[39] European Commission. Soil Contamination: Impacts on Human Health. Bristol, England: Science for Environment Policy, 2013.
[40] Soil pollution: Causes, effects and control. Dr. Rajesh Kumar Mishra, Dr. Naseer Mohammad and Dr. N. Roychoudhury. 2016, ResearchGate, pp. 1-14.

[41] European Commission. Soil contamination impact on human health. s.1.: European Commission, 2013.

[42] Landim, Pedro Correia. effect of pesticides on farmers. [interv.] Namir Domingos Raimundo Lopes. August 13, 2017.

[43] Djatá, Rui N. [interv.] Namir D. R. Lopes. August 5, 2017.

[44] CCICED. Special Policy Study on Soil Pollution Management China: China Council for International Cooperation on Environment and Development (CCICED), 2015.

[45] UNEP. SOLID WASTE MANAGEMENT. USA: UNEP, 2015.

[46] Dias, Odonio. Solid waste management in Guinea-Bissau. [interv.] Namir Domingos Raimundo Lopes. July 15, 2017.

[47] Lopes, João Raimundo. Soil contaminants control methods in Guinea-Bissau. [interv.] Namir Domingos Raimundo Lopes. August 10, 2017.

[48] Tasie, Boubacar Diallo and Oyinkan. National Implementation of Regional Pesticide Policies In West Africa: The Gambia Case Study Report. Banjul: Food Security Policy Research Papers, 2017.

[49] FAO. Rotterdam Convention Sub-regional Meeting gathers representatives from Lusophone African countries to discuss on pesticides in Cabo Verde. Food and Agriculture Organization of the United Nations. [Online] March 6, 2017. [Cited: December 24, 2017.] http://www.fao.org.

[50] CAIA. Soil contaminants prevention and control in GuineaBissau. [interv.] Namir Domingos Raimundo Lopes. August $16,2017$.

[51] UNEP. National 1mplementation Plan for the Stockholm Convention on Persistent Organic Pollutants (POPS). Abuja, Nigeria: UNEP-POPS-NIP-Nigeria, 2015.

[52] STOCKHOLM CONVENTION ON PERSISTENT ORGANIC POLLUTANTS (POPs). STOCKHOLM: Secretariat of the Stockholm Convention on Persistent Organic Pollutants, 2009.

[53] Inventario de pesticidas na Guiné-Bissau. UNEP. [Online] January 22, 2015. [Cited: December 24, 2017.] www.pic.int.

[54] Rotterdam Convention. ON THE PRIOR INFORMED CONSENT PROCEDURE FOR CERTAIN HAZARDOUS CHEMICALS AND PESTICIDES IN INTERNATIONAL TRADE. Rotterdam: Rotterdam Convention, 2013.

[55] Rotterdam Convention Ratification in Guinea-Bissau. Bissau: Rotterdam Convention, 2013.

[56] FAO. Dakar meeting on the Rotterdam Convention in the 13 CILSS countries. Dakar: FAO, 2016.

[57] Countrymeter. Nageria population. Countrymeter. [Online] January 1st, 2017. [Cited: December 10, 2017.] http://countrymeters.info/en/Nigeria.

[58] Green Pesticides in Nigeria:An Overview. Lami A. Nnamonu, Amana Onekutu. 2015, Journal of Biology, Agriculture and Healthcare. 
[59] Afua B. Banful, Ephraim Nkonya, Victor Oboh. Constraints to Fertilizer Use in Nigeria: Perspectives and Insights from the Agricultural Extension Service. Nigeria: nigeria.countrystat.org, 2014.

[60] FAO. Food Security Statistics- Nigeria. Roma: FAOSTAT, 2012.

[61] Problems associated with pesticide usage and application in Nigerian cocoa production: A review. Dongo, E. U. Asogwa and L. N. 2009, African Journal of Agricultural Research Vol. 4, pp. 675-683.

[62] Shaibu, Inalegwu. 30 Agrochemical Products Banned in Nigeria After Deaths. Nigeria: organicconsumers.org, 2008.

[63] NLIPWatch. Guidelines for Pesticides Resgistration in Nigeria.
NLIPWatch. [Online] December 9, 2017. [Cited: December 22, 2017.] https://nlipw.com.

[64] Bello, Mallam Adamu. NATIONAL FERTILIZER POLICY FOR NIGERIA. Nigeria: Federal Ministry of Agriculture and Rural Development, 2014.

[65] Constraints to fertilizer use in Nigeria. BANFUL, AFUA BRANOAH, NKONYA, EPHRAIM and OBOH, VICTOR. 2010, IFPRI DISCUSSION PAPER, pp. 1-28.

[66] FAO. Food Security Statistics- Nigeria. Roma: FAOSTAT, 2012.

[67] DENARP II. Segundo Documento de Estratégia Nacional de Redução da Pobreza. Bissau: MINISTÉRIO DA ECONOMIA, PLANO E INTEGRAÇÃO REGIONAL, 2016. 